\title{
Adapting the Robust Design Methodology to support sustainable product development
}

\author{
Ida Gremyr ${ }^{\text {a }}$, Vanajah Siva ${ }^{a,}$, Hendry Raharjo ${ }^{a}$, Thong Ngee Goh ${ }^{b}$ \\ a Division of Quality Sciences, Chalmers University of Technology, SE-41296, Sweden \\ ${ }^{\mathrm{b}}$ Department of Industrial \& Systems Engineering, National University of Singapore, Singapore 117576, Singapore
}

\section{A R T I C L E I N F O}

Article history:

Received 24 January 2014

Received in revised form

8 May 2014

Accepted 8 May 2014

Available online 27 May 2014

Keywords:

Sustainable product development

Quality Management

Robust Design Methodology

Sustainability

\begin{abstract}
A B S T R A C T
Research on product development has pointed to a challenge in integrating sustainability considerations into existing engineering practices rather than adding additional sets of practices and tools. The question is what practices are suitable for consideration? One set of practices and tools, deemed suitable due to its focus on long-term impacts and customer focus, is Quality Management. Within this area, the Robust Design Methodology has a historic connection to sustainability vis-à-vis quality loss caused by a product not only to an individual customer, but to society at large. Hence, there appears to be a neglected connection to the sustainability area. This paper explores how efforts based on the Robust Design Methodology may better contribute to sustainability and, more specifically, to sustainable product development. This paper reviews earlier Robust Design Methodology case studies that reveal how it supports sustainability. However, the reviews also reveal that efforts so far have focused only on the manufacturing and use phases of a product's lifecycle. Hence, adaptations of the methodology are needed, such as more conceptual and qualitative tools and explicit inclusion of eco-design indicators as a response variable in, for example, Design of Experiments. Adapting the Robust Design Methodology enables meeting the key aspects of an eco-design tool: addressing early integration of environmental aspects in development processes, having a lifecycle approach, and being a multi-criteria approach.
\end{abstract}

(C) 2014 Elsevier Ltd. All rights reserved.

\section{Introduction}

Many authors have argued that it is necessary to integrate sustainability considerations throughout product development processes (Masui et al., 2003; Maxwell and Van der Vorst, 2003; Luttropp and Lagerstedt, 2006). One such integration involves elaborating and adapting existing engineering practices and techniques to overcome the perception of eco-design tools as "tools for experts" (Knight and Jenkins, 2009) (p. 550). For example, Quality Management $(\mathrm{QM})$ can benefit such an integration due to its emphasis on the customer and continuous improvement (Dean $\mathrm{Jr}$ and Bowen, 1994). As stated by Lopes Silva et al. (2013, p. 175), $\mathrm{QM}$ is useful as it is, "well known, corroborated and integrated into most organizations' management processes, familiar to most

Abbreviations: DfE, Design for Environment; NF, noise factors; P-diagram parameter diagram; QFD, Quality Function Deployment; QM, Quality Management; RDM, Robust Design Methodology; SPD, sustainable product development; TIPS, Theory of Inventive Problem Solving.

* Corresponding author.

E-mail address: vanajah.siva@chalmers.se (V. Siva). managers and also very easy to adapt to an environmental program”. Sustainability research within QM has addressed a variety of areas such as integrated environmental management systems (Tarí and Molina-Azorín, 2010), adaptations of tools, such as Quality Function Deployment (QFD), in contributing toward the Design for Remanufacture (Hatcher et al., 2011), and the role of QM for the success of environmental management practices (Wiengarten and Pagell, 2012).

QM is defined as, "a philosophy or an approach to management that can be characterized by its principles, practices, and techniques. Its three principles are customer focus, continuous improvement, and teamwork" (Dean Jr and Bowen, 1994). An early description of quality by Shewhart (1931) (p. 53) reads as follows: "One of these [aspects of quality] has to do with the consideration of the quality of a thing as an objective reality independent of man. The other has to do with what we think, feel, or sense as a result of the objective reality. In other words, there is a subjective side of quality". The subjective aspect of quality in QM has generally been interpreted as individual customers' needs and wants.

One QM methodology is the Robust Design Methodology (RDM), which is defined as "systematic efforts to achieve insensitivity to 
noise factors. These efforts are founded on an awareness of variation and can be applied in all stages of product design" (Arvidsson and Gremyr, 2008) (p. 31). Taguchi, an early proponent of the RDM, defined quality in a way that profoundly differs from other early proponents. Taguchi (1986), p. 1) considered quality loss as "the loss a product causes to society after being shipped, other than any losses caused by its intrinsic functions". In this definition, the customer, as the final arbiter of quality, has not been replaced, but rather significantly expanded to society at large. Taguchi does not elaborate on this role, but states that, "what functions society should allow products to have is a cultural and legal problem, not an engineering problem" (Taguchi, 1986) (p. 3).

However, negative impacts to society in terms of, for example, environmental damage, have today reached levels that make sustainability a challenge to all disciplines, including engineering. In the development and production of goods, there are opportunities to make changes that support sustainability. Sustainability studies are not extensive in the RDM literature. One notable example is Ben-Gal et al. (2008) who proposed using the Taguchi method for the eco-design of a factory smokestack. Other examples are Fratila and Caizar (2011) and Hanafi et al. (2012), who described power reduction applications in machining processes.

The examples of applying the RDM have shown that it might be useful in supporting sustainability. However, still lacking is the answer to necessary adaptations of the RDM in early product development phases. The purpose of this paper is to explore how efforts based on the RDM may better contribute to sustainability and, more specifically, to sustainable product development (SPD). Section 2 reviews the RDM and SPD literature. Section 3 describes the method used for the study. An analysis of the interrelationships between the RDM and SPD is carried out in Section 4 using a selection of published case studies. The analysis is followed by discussions in Section 5 and finally conclusions in Section 6.

\section{Literature review}

The two following subsections will review main ideas underlying the RDM and SPD areas. Further, to identify needed RDM sustainability adaptations, each sub-section will end by pointing to future research.

\subsection{The Robust Design Methodology}

Over time, a number of authors have argued that variation among units of the same product would lead to dissatisfied customers (Shewhart, 1931; Phadke, 1989). Taking into account that uncontrollable noise factors (NFs) may cause a product characteristic to deviate from its specified target, a tolerance interval is assigned to a target. In Taguchi's 1993 terminology, these deviations cause quality losses. Quality loss is further elaborated by Taguchi (1993) (p. 4) as "the amount of functional variation of products plus all possible negative effects, such as environmental damages and operational costs". As discussed by Kackar (1985), a traditional view of quality loss inside the tolerance interval is zero. An alternative view is the quadratic loss function (Taguchi and Wu, 1979; Taguchi, 1986). Quality loss implies that a customer is most satisfied when the performance characteristic is on target, but becomes gradually dissatisfied when the value approaches tolerance limits.

One way to conceptually analyze NFs and their influence on a product or process is by using a P-diagram (see Fig. 1), which relates an input into a system (signal factor) to a desired output (response variable) while at the same time considering control factors (Phadke, 1989). Later versions of the P-diagram also add various error states as outputs, that is, undesired outputs (Davis, 2006).

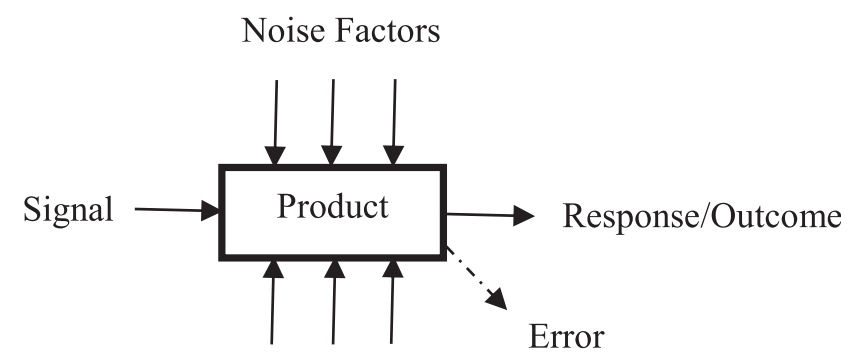

Control Factors

Fig. 1. P-diagram.

The prevalent and well-known NF categorization by Taguchi and Wu (1979) allowed for not limiting outer disturbances to actions taken by a customer or product user. Thus, it is consistent in defining quality loss as losses to society. However, later NF categorizations have become narrower in scope (see Table 1). The broad label of "outer disturbances" has been interpreted, or rephrased, into "variations in condition of use" (Clausing, 1994) or "customer duty cycles" (Davis, 2006). These examples show a change of interpretation from society at large to a single customer or user, although society at large can also affect the product, for example, through legislations and regulations.

Efforts to create NF insensitivity are often divided into two categories based on the application point in a product life-cycle (Taguchi, 1986). On-line efforts are applied during manufacturing and off-line efforts in both designing products and manufacturing processes (Kackar, 1989). In summary, the chances of reducing NF influence increase if the efforts are applied off-line (see Table 2).

Many authors, such as Kackar (1985), Taguchi and Phadke (1989), Taguchi and Clausing (1990), and Box et al. (1988), emphasized applying the RDM proactively when designing products and processes. Despite this emphasis, Thornton et al. (2000) discovered in their study that fewer than half the companies used the RDM proactively. With reference to Table 2, this excludes the possibility of designing a product being robust to variations in conditions of use and deterioration.

One reason for the shortfall in applying the RDM proactively might be found in previous research, which often focused on tools such as Design of Experiments, while neglecting the practices and the question of when to apply the tools (Arvidsson and Gremyr, 2008; Hasenkamp et al., 2009). Addressing these areas has been argued as critical for the RDM's application (Gremyr et al., 2003; Gremyr and Hasenkamp, 2011). Another area in need of future development is practices and tools that can be used in early product development phases when quantitative data is not available (Ford, 1996; Andersson, 1997). In addition, parallel development of the tools, such as research on multiple responses in designed experiments (Jeyapaul et al., 2005; Murphy et al., 2005), is still beneficial.

\subsection{Sustainable product development}

Since the early 1990s, the sustainable development boom has prompted discussion of environmental concerns in relation to product development and manufacturing (Baumann et al., 2002). On the subject of eco-design, much focus has been aimed at the inclusion of environmental considerations in existing engineering tools, such as the Kano model, Quality Function Deployment (QFD) and the Theory of Inventive Problem Solving (TIPS) (Bovea and Pérez-Belis, 2012). Enhancement is seen as a viable approach to addressing the gap between the demand for existing tools and emerging theories, such as eco-design (Sakao, 2007, 2009). 
Table 1

Examples of noise factor categories.

\begin{tabular}{|c|c|c|c|}
\hline Description of category & Taguchi and Wu (1979) & Clausing (1994) & Davis (2006) \\
\hline $\begin{array}{l}\text { Factors external to the } \\
\text { company }\end{array}$ & Outer disturbances & Variation in condition of use & $\begin{array}{l}\text { Customer duty cycles } \\
\text { External environmental conditions induced by climate conditions } \\
\text { and road inputs }\end{array}$ \\
\hline $\begin{array}{l}\text { Factors internal to the } \\
\text { company }\end{array}$ & Manufacturing disturbances & Production variation & $\begin{array}{l}\text { Variation of part characteristic due to production conditions } \\
\text { Internal environmental conditions caused by complexity-induced } \\
\text { interactions of neighboring components }\end{array}$ \\
\hline Variation over time & Inner disturbances & Deterioration & Variation of part characteristic over time in the field \\
\hline
\end{tabular}

Adopting eco-design is increasingly exemplified in recent literature. Bovea and Pérez-Belis (2012) argued that there are three key factors: early integration of environmental aspects, adopting a lifecycle approach, and a multi-criteria approach. A couple of examples of eco-design practices are the use of checklists and material, energy and toxicity matrices (Knight and Jenkins, 2009), and selecting indicators based on existing production data, such as the weights of reusable and recyclable parts, and the time for disassembly (Cerdan et al., 2009).

Integrating sustainability has been argued as a necessary step in all stages of a product lifecycle (Kaebernick et al., 2003), not just the production stage alone. A step backward is necessary to revisit and restructure the product development process (Waage, 2007). Sustainable production has been defined as an integrated approach where environmental requirements are considered at every stage of product development (Vinodh and Rathod, 2010). Moving from the earlier efforts of end-of-line initiatives and measures, such as emission control and product disposal systems, sustainability considerations have moved upstream to the development and design stages of products (Johansson, 2002).

One approach toward integrating environmental considerations is Design for Environment (DfE), which has been defined as "the systematic consideration of design performance with respect to environmental, health, safety, and sustainability objectives over the full product and process lifecycle" (Fiksel, 2011) (p. 83). As argued by Knight and Jenkins (2009), it is necessary to consider the broad impact of design from raw material extraction to end of life. Based on this insight, five DfE strategies have been defined (Choi et al., 2008) (see Table 3 below).

During the raw material stage, DfE stipulates selecting material based on its environmental effectiveness and properties appropriate to recycling or remanufacturing. During manufacturing, each process is designed to be conducive to enhancements, such as protection against operator variability, material waste minimization, and machine utilization optimization, to name a few. Distributing finished goods in terms of product weight is considered to maximize transportation efficiency. In the product use stage, the user variation and usage conditions must be taken into consideration to ensure that waste is controlled or minimized. Endof-product-life strategies must also be in place in order to optimize disposal methods via recycling, reuse or remanufacturing.

\section{Table 2}

Development stages during which countermeasures against categories of noise are possible, adapted from Kackar (1989).

\begin{tabular}{llll}
\hline Development & \multicolumn{2}{l}{ Category of noise factor } & \\
\cline { 2 - 4 } stages & $\begin{array}{l}\text { Variation in conditions } \\
\text { of use }\end{array}$ & $\begin{array}{l}\text { Production } \\
\text { variations }\end{array}$ & Deterioration \\
\hline Product design & $\mathrm{X}$ & $\mathrm{X}$ & $\mathrm{X}$ \\
Process design & & $\mathrm{X}$ & \\
Manufacturing & & $\mathrm{X}$ & \\
\hline
\end{tabular}

$\mathrm{X}=$ Countermeasure possible.
A number of barriers to sustainability in engineering practices have been identified, for example the lack of integration and systematic implementation continuity, and resistance to change (Lopes Silva et al., 2013). In the analyses of the eco-design and product development processes, Knight and Jenkins (2009) as well as Bovea and Pérez-Belis (2012) pointed to tools which are closely linked to QM, for example, environmental effect analysis or Environmental Failure Mode Effects Analysis and environmental, or green, QFD. Knight and Jenkins (2009), however, pointed to the need to adapt such tools to suit specific needs of the development process.

\section{Methods}

This paper is based on a conceptual method integrating "a number of different works on the same topic, summarizes the common elements, contrasts the differences, and extends the work in some fashion" (Meredith, 1993) (p. 8). Linking to the description by Macinnis (2011) of four general conceptual goals, that is, envisioning, explicating, relating, and debating, this paper aims at relating the RDM to SPD. Further, the relating is based on a specific goal of integration, that is, "to see previously distinct pieces as similar, often in terms of a unified whole" (p. 138). The integration of the RDM and SPD is based on each concept's underlying ideas, along with secondary data from published case studies. The flow of the literature search for the case studies is shown in Fig. 2 below, followed by a discussion on criteria for case study selection.

The cases were identified through searches during September 2013 in four search engines, Scopus, Science Direct, Web of Knowledge, and Google Scholar. Two groups of search words were used in all databases. Search words used in the first group included "robust design", "case study", "manufacturing" and "eco-design". This search resulted in 77 published case studies. Search words in the second group included "robust design", "case study", "manufacturing" and "sustainability", resulting in 84 published case studies.

In order to gather secondary data, the previously published case studies had to fulfill the following criteria: 1) dealing with the RDM, 2 ) establishing the potential connections to sustainability benefits, for example, reduced energy consumption or emissions, and 3) be applied in or concern a manufacturing setting. The first two criteria are motivated by the purpose of the study aiming at the RDM as a methodology and its contribution to SPD. The third criterion is

Table 3

Design for environment strategies (adapted from Choi et al. (2008)).

\begin{tabular}{ll}
\hline Lifecycle stage & DfE strategies \\
\hline Raw material & Material use optimization \\
Manufacturing & Clean manufacturing \\
Distribution & Efficient distribution \\
Product use & Clean use/operation \\
End of life & End of life optimization \\
\hline
\end{tabular}




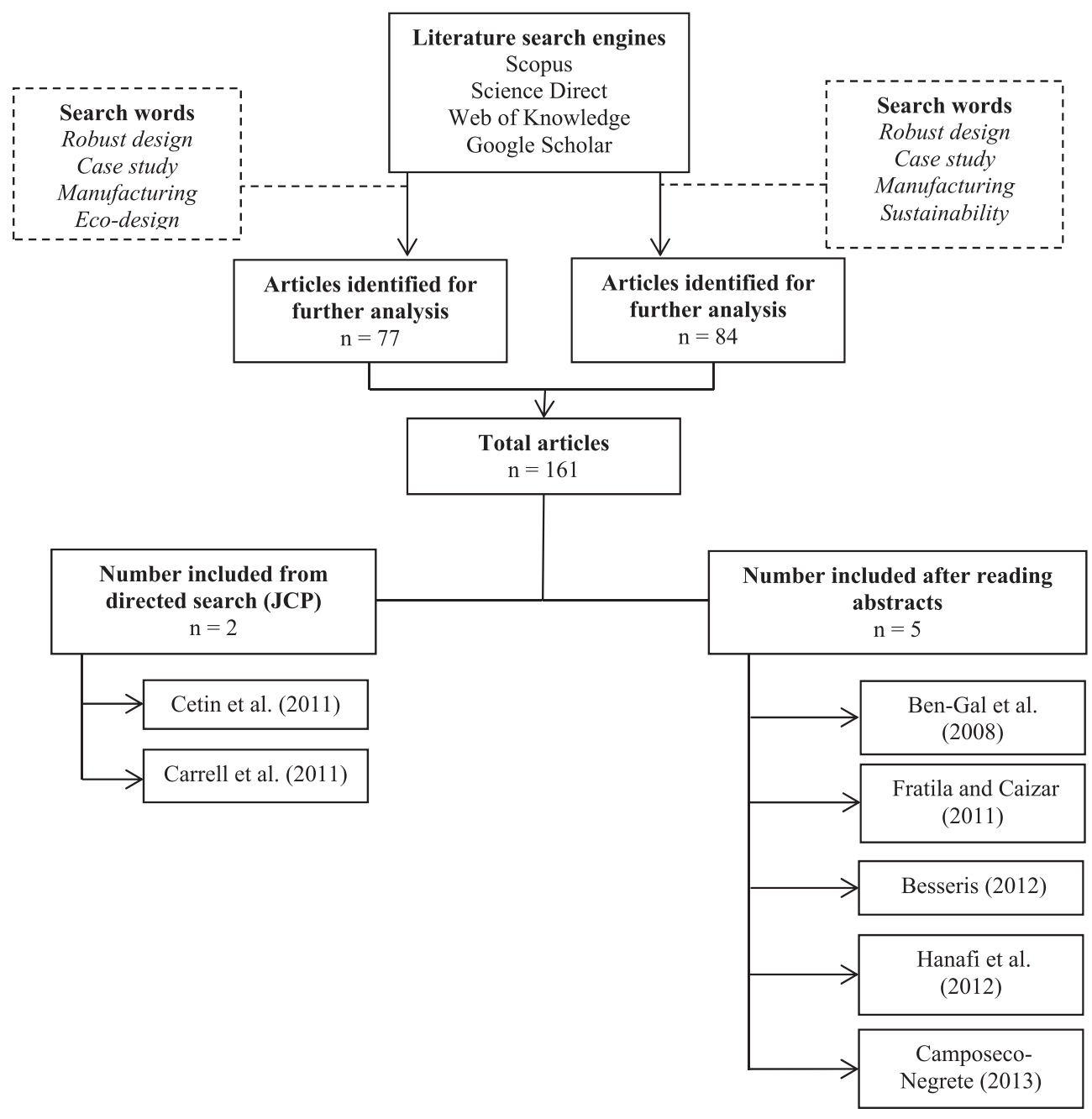

Fig. 2. Literature search flow.

motivated by the claimed differences in practices of QM between a service and manufacturing context (Rönnbäck and Witell, 2008). The abstracts of all 161 case studies were reviewed, resulting in the selection of five case studies. In addition, a directed search was conducted in the SPD-focused Journal of Cleaner Production, resulting in two additional case studies. The final number of studies selected was seven.

\section{Overview of the case studies}

The selected case studies span a variety of industrial applications; an overview of the cases is shown in Table 4. For each study, an overall problem description is given to provide context. In addition, the third column addresses the RDM tools that were applied. The next three columns follow the P-diagram format (Fig. 1): control factors, noise factors, and response variables. The outcomes are as reported by the respective authors, whereas the final column is an interpretation of the lifecycle stage during which the RDM efforts have been made.

\subsection{Common features of the case studies}

On an overall level, the case studies show that efforts have been made to apply the RDM to support sustainability. It is not difficult to conclude that increased yield, decreased failures, and less scrap is beneficial from a sustainability standpoint. Therefore, it has been argued that using the RDM contributes in general to sustainability. The cases span a variety of applications, but do have some common traits. First, all but one case (Ben-Gal et al., 2008) concern the design of cutting and milling processes. Second, sustainability has been included either by choosing a response variable related to environmental pollution, for example, power consumed (Camposeco-Negrete, 2013), or a control factor capturing the levels of an environmentally hazardous component, for example, a lubricant (Fratila and Caizar, 2011). Another example is using environmentally friendly material as one of the control factors (Cetin et al., 2011). Third, all the case studies have applied quantitatively based tools from the RDM. These tools have been applied in a standard manner with no adaptations. Fourth, the RDM has been applied in the detailed design phase as a means of setting variable levels. No application has been reported for the conceptual design phases in which quantitative data might be lacking, whereas the opportunties to create a robust design may be considerable (Andersson, 1997).

\subsection{Analysis of the Robust Design Methodology efforts}

In their work on DfE strategies, Choi et al. (2008) linked environmental sustainability efforts to lifecycle stages as displayed in Table 3. The reduction of scrap and decreased early-life product 
Table 4

Overview of the case studies.

\begin{tabular}{|c|c|c|c|c|c|c|c|}
\hline Source & Problem description & $\begin{array}{l}\text { Robust design tools } \\
\text { applied }^{\mathrm{a}}\end{array}$ & Control factors & Noise factors ${ }^{\mathrm{b}}$ & Response variables & $\begin{array}{l}\text { Reported outcomes as } \\
\text { described in case studies }\end{array}$ & $\begin{array}{l}\text { Life cycle stage where } \\
\text { RDM tools were applied }\end{array}$ \\
\hline $\begin{array}{l}\text { Ben-Gal et al. } \\
\text { (2008) }\end{array}$ & $\begin{array}{l}\text { Minimizing factory stack } \\
\text { emissions to guarantee an } \\
\text { environmentally sound system }\end{array}$ & $\begin{array}{l}\text { Non-linear transfer } \\
\text { function }\end{array}$ & $\begin{array}{l}\text { Stack design parameters, that is, } \\
\text { height and diameter }\end{array}$ & $\begin{array}{l}\text { Weather conditions, } \\
\text { that is, ambient } \\
\text { temperature and } \\
\text { wind speed }\end{array}$ & $\begin{array}{l}\text { Emission of air } \\
\text { pollutant }\end{array}$ & $\begin{array}{l}\text { Design of factory stacks } \\
\text { that emits regulated air } \\
\text { pollutant level }\end{array}$ & Design stage \\
\hline Cetin et al. (2011) & $\begin{array}{l}\text { Reduction of surface roughness, } \\
\text { and cutting and feed forces } \\
\text { during turning process of } \\
\text { stainless steel }\end{array}$ & $\begin{array}{l}\text { Taguchi's mixed level } \\
\text { parameter design (L18) } \\
\text { orthogonal array as } \\
\text { experimental design }\end{array}$ & $\begin{array}{l}\text { Turning parameters -spindle speed, } \\
\text { depth of cut, feed rate, viscosity }\end{array}$ & - & $\begin{array}{l}\text { Surface roughness, } \\
\text { cutting force, feed } \\
\text { force }\end{array}$ & $\begin{array}{l}\text { Optimal conditions of } \\
\text { cutting parameters were } \\
\text { identified to reduce } \\
\text { cutting force and improve } \\
\text { the surface finish }\end{array}$ & $\begin{array}{l}\text { Design of the turning } \\
\text { process }\end{array}$ \\
\hline Carrell et al. (2011) & $\begin{array}{l}\text { Simplifying disassembly by } \\
\text { engineering a snap-fit for } \\
\text { automatic release upon } \\
\text { exposure to heat field to limit } \\
\text { manual labor or machine } \\
\text { operation for disassembly }\end{array}$ & $\begin{array}{l}\text { Taguchi methods } \\
\text { incorporated in a set of } \\
\text { designed experiments }\end{array}$ & $\begin{array}{l}\text { Method of heating (oil bath or air } \\
\text { bath), temperatures for disassembly }\end{array}$ & $\begin{array}{l}\text { Variable dimensions } \\
\text { of the snap-fits } \\
\text { (Length, overhang, } \\
\text { thickness, release } \\
\text { angle) }\end{array}$ & $\begin{array}{l}\text { Shortest time for } \\
\text { disassembly }\end{array}$ & $\begin{array}{l}\text { Minimal time for } \\
\text { disassembly was achieved } \\
\text { based on optimal process } \\
\text { conditions }\end{array}$ & $\begin{array}{l}\text { Design of end-of-life } \\
\text { process }\end{array}$ \\
\hline $\begin{array}{l}\text { Fratila and Caizar } \\
\text { (2011) }\end{array}$ & $\begin{array}{l}\text { Optimizing cutting parameters } \\
\text { for good surface finish } \\
\text { (roughness) and minimum } \\
\text { power consumption }\end{array}$ & $\begin{array}{l}\text { Taguchi method using } \\
\text { orthogonal arrays }\end{array}$ & $\begin{array}{l}\text { Milling parameters - axial cutting } \\
\text { depth, feed rate, cutting speed and } \\
\text { lubricant flow rate }\end{array}$ & - & $\begin{array}{l}\text { Finish surface } \\
\text { roughness and } \\
\text { cutting power }\end{array}$ & $\begin{array}{l}\text { Optimum cutting } \\
\text { conditions to successfully } \\
\text { apply near-dry techniques } \\
\text { for cutting processes } \\
\text { were established }\end{array}$ & $\begin{array}{l}\text { Design of milling } \\
\text { process }\end{array}$ \\
\hline Hanafi et al. (2012) & $\begin{array}{l}\text { Optimize cutting parameters } \\
\text { to achieve minimum power } \\
\text { consumption and the best } \\
\text { surface quality }\end{array}$ & $\begin{array}{l}\text { Taguchi method coupled } \\
\text { to grey relational analysis }\end{array}$ & $\begin{array}{l}\text { Machining parameters - cutting } \\
\text { speed, feed rate and depth of cut }\end{array}$ & - & $\begin{array}{l}\text { Surface roughness } \\
\text { and cutting power }\end{array}$ & $\begin{array}{l}\text { Optimal conditions of } \\
\text { cutting parameters were } \\
\text { identified }\end{array}$ & $\begin{array}{l}\text { Design of cutting } \\
\text { process }\end{array}$ \\
\hline Besseris (2012) & $\begin{array}{l}\text { Minimize environmental } \\
\text { quality indicators such as } \\
\text { chemical oxygen demand } \\
\text { (COD) and biochemical oxygen } \\
\text { demand (BOD) in milk } \\
\text { wastewater treatment }\end{array}$ & $\begin{array}{l}\text { Taguchi method, 8-run } \\
\text { saturated orthogonal } \\
\text { array }\end{array}$ & $\begin{array}{l}\text { Acidity, dissolved oxygen, quantity } \\
\text { of incoming wastes, sludge volume } \\
\text { index and mixed liquor suspended } \\
\text { solids }\end{array}$ & - & $\begin{array}{l}\text { Values of COD and } \\
\text { BOD }\end{array}$ & $\begin{array}{l}\text { Minimum values for the } \\
\text { quality indicators were } \\
\text { identified }\end{array}$ & $\begin{array}{l}\text { Design of wastewater } \\
\text { treatment process }\end{array}$ \\
\hline $\begin{array}{l}\text { Camposeco-Negrete } \\
\text { (2013) }\end{array}$ & $\begin{array}{l}\text { Optimize cutting parameters for } \\
\text { minimum energy consumption }\end{array}$ & $\begin{array}{l}\text { Taguchi method, } \\
\text { orthogonal array }\end{array}$ & $\begin{array}{l}\text { Depth of cut, feed rate and cutting } \\
\text { speed }\end{array}$ & - & $\begin{array}{l}\text { Cutting power } \\
\text { consumed, cutting } \\
\text { energy consumed } \\
\text { and surface } \\
\text { roughness }\end{array}$ & $\begin{array}{l}\text { Most significant factor } \\
\text { for minimized energy } \\
\text { consumption and improved } \\
\text { surface roughness } \\
\text { (feed rate) was identified }\end{array}$ & $\begin{array}{l}\text { Design of cutting } \\
\text { process }\end{array}$ \\
\hline
\end{tabular}

b Blank cells in the "Noise factors" column indicate that the experiments were designed to determine the main control factor effects to establish the optimal conditions. 
failures are examples of evident synergies between the RDM efforts and DfE strategies. Three reasons explain this outcome. First, the NF categorization, for example, Clausing (1994) (see Table 1) may explain why the focus is on clean manufacturing and use. The first two NF categories are related to the manufacturing and use stages of a product. Second, the focus of the majority of the RDM's efforts has not been on the upstream operations in organizations (Thornton et al., 2000), but rather on the manufacturing stage despite broad agreement on the need to apply the RDM upstream (for example, Kackar (1985), Phadke (1989), and Box et al. (1988)). Third, in broadening the impact of the RDM to sustainability, both the qualitative and quantitative methods are needed. Moreover, the adaptations and changes of the methods, rather than merely adding on the sustainability perspectives, appear vitally and urgently needed. Each of these areas will be elaborated on in the following.

First, one way of increasing the RDM's contribution to sustainability would be to broaden the number of NFs taken into account. This approach would require reclaiming the view of quality loss as a loss to the society and not merely to a specific customer (Taguchi and $\mathrm{Wu}, 1979)$. In Taguchi's definition, the lack of product quality or the existence of non-robust products would create losses not only for a particular customer, but for the society at large. By such a broad view, it would be possible to realize the potential impact of the eco-design in the stages, such as raw material extraction and end-of-life (Knight and Jenkins, 2009). For example, in the cases involving improving product surfaces (Cetin et al., 2011; Fratila and Caizar, 2011; Hanafi et al., 2012; Camposeco-Negrete, 2013), the studies identified optimal conditions via a specific type of designed experiments. The case studies, however, did not elaborate further on the social implications or benefits of these results for the business organizations or their customers. What effect would such an improvement have on the customers? What would the waste reduction be in terms of the reduced scraps achieved by improving the surface? What would be the effect of such improvement on the environment and society? A critical view of the RDM applications is required in order to address these questions for better use of this methodology.

Second, the focus of the RDM efforts throughout the case studies has, as earlier stated, been on the detailed development phases (Ben-Gal et al., 2008) and manufacturing (Cetin et al., 2011; Fratila and Caizar, 2011; Besseris, 2012; Hanafi et al., 2012; CamposecoNegrete, 2013). Although the RDM efforts have today been weakly linked to the raw material, distribution, and end-of-life phases, the DfE strategies can be applied throughout all life-cycle stages, as proposed by Choi et al. (2008). The possible contributions should be further elaborated upon to support lifecycle sustainability and, at the same time, the development of the RDM in terms of continuous applicability (Hasenkamp et al., 2009). This would require the use and adaptation of conceptual methods such as the P-diagram (see Fig. 1) to encompass sustainability considerations.

Third, to be able to increase the RDM's contribution to sustainability, the supportive tools need to be changed and developed. As an example, various Design of Experiment techniques (for example, Taguchi arrays or Taguchi methods) have so far been applied without further adjustment. The lubricant flow rate as a control factor as reported by Fratila and Caizar (2011) offers an example. Another example involves analyzing process parameters affecting product disassembly time (Carrell et al., 2011). From an operational point of view, it would be interesting to adopt Design of Experiment as a tool supporting sustainability. An approach would be to alter the responses studied not only to capture the main process output, but also to use multiple responses. A multi-response optimization approach to the RDM using one or more sustainability indicators (for example, $\mathrm{CO}_{2}$ emissions) as the response variables may increase the RDM's contribution to sustainability. This could also build on the work by
Cerdan et al. (2009), aiming to create simple eco-design indicators that build on production-related measures such as disassembly time. The advantage of adding relevant sustainability indicators would be to control the level and variance of response variables considering the desired condition (for example, lower-the-better, higher-thebetter, or nominal target) and their relationships to other performance-based or process-based response variables. With respect to the trade-offs among response variables, a sound compromise may be required taking into account related practical constraints, for example, users' risk attitude. A review of various methods for multi-response robust design can be found in Jeyapaul et al. (2005) and Murphy et al. (2005). Furthermore, to accommodate the need for upstream efforts, the qualitative methods, such as the Pdiagram, would be desirable. Through such methods, the opportunities for early development phase robustness and decreased waste that can only be captured when the quantitative data is not available can be exploited.

\section{Discussion}

Within the SPD area, the need for integrating sustainability in product development is well recognized (Lopes Silva et al., 2013). One focus area is sustainability integration in engineering practices, where eco-design tools are at times adaptations of tools from the QM area, for example, QFD (Knight and Jenkins, 2009). To be considered an eco-design tool means integrating environmental aspects early in the development processes, as well as adopting a multi-criteria and lifecycle approach (Bovea and Pérez-Belis, 2012). The multi-criteria approach is important as it facilitates trade-offs between various output variables.

The RDM is an existing set of engineering practices and tools from the QM area that historically has a link to sustainability through its definition of quality loss (Taguchi, 1993). Over the years, the main focus has, however, been on the loss to the individual customer. In line with the current focus on sustainability in the area of product development (Baumann et al., 2002), the time has come to return to the original focus. If the NF categories had remained closer to the original thinking, the links between the RDM and SPD might have attracted greater attention. Thus, the RDM efforts should focus not only on minimizing unwanted variations in the output experienced by the customer, but also on the minimization of environmental damages.

In the area of sustainability, the focus is shifting from the endof-product-life view to one of continuous product development applicability (Johansson, 2002), which is also an underlying principle of the RDM (Arvidsson and Gremyr, 2008) and an area in need of further research (Ford, 1996; Andersson, 1997). Hence, practices and tools for the upstream efforts are needed in both the RDM and SPD. An example would be to explicitly focus on the environmental effects in the conceptual stages of the P-diagram by including a sustainability indicator as a response. Such an indicator could stimulate considering noise factors, such as material hazardousness or the limited access to certain materials. The goal of the P-diagram might then be expanded from functional robustness to also include minimizing the use of, and decreasing the dependence on, certain material. In this way, the P-diagram might support a broad range of the DfE strategies (Choi et al., 2008).

Besides the focus on adapting the RDM to better support a broader range of lifecycle phases and the early development stages, the adaptations of standard tools such as Design of Experiment have been suggested. These suggestions are focused on the application of multiple responses (Jeyapaul et al., 2005; Murphy et al., 2005), one being an eco-indicator (Cerdan et al., 2009). In other words, the responses should not only capture the loss to individual customers, but also the loss to the society. Along with such a 
development, the need will arise to conduct research on the customer's willingness, or lack thereof, to pay for products that minimize the loss to society. In summary, the suggested adaptations of the RDM will aid in, "the integration of environmental aspects into the early stages of the design process together with a multi-criteria approach that makes it possible to balance the environmental requirements against other traditional requirements [which] are two of the key factors for successful sustainable design" (Bovea and Pérez-Belis, 2012) (p. 61).

\section{Conclusions}

The purpose of this paper is to explore how the RDM efforts may better contribute to sustainability and, more specifically, to SPD. This paper points to the RDM as a set of engineering practices and tools that can integrate sustainability considerations throughout the product development processes. To better contribute to SPD, two adaptation areas of the RDM are in need of further research. First, it is argued that the RDM has potential to contribute to all lifecycle stages. However, in order to exploit this potential a number of adaptations are needed. It is important to have a broader view on the NFs and not limit these to an individual customer's use of the product. Further, more focus is needed on the early product development phases, which will require the application of conceptual and qualitative tools. Second, it is insufficient to merely apply tools that are supportive of the RDM as is. These tools have to be adapted to include sustainability considerations explicitly. One example is to add the eco-design indicators as a second response variable.

By adapting the RDM as suggested, for example by focusing on early product development phases and including eco-design indicators in supportive tools, the RDM can better contribute to SPD. The adapted RDM will successfully fulfill the key criteria for the eco-design tools, namely, an early integration of environmental aspects in the development processes, adopting a lifecycle approach and a multi-criteria approach. In addition, the future research identified in this paper will contribute to SPD by aiding integration into the current engineering practices. The contributions to the RDM are to support the development of tools applicable in the early product development phases, and to exploit the sustainability opportunities throughout the product lifecycle.

\section{Acknowledgements}

This work has been carried out within the Sustainable Production Initiative and the Production Area of Advance at Chalmers. The support is gratefully acknowledged. Further, we are grateful for the constructive review comments we have received on earlier drafts of this paper.

\section{References}

Andersson, P., 1997. On robust design in the conceptual design phase: a qualitative approach. J. Eng. Des. 8, 75-89.

Arvidsson, M., Gremyr, I., 2008. Principles of robust design methodology. Qual. Reliab. Eng. Int. 24, 23-35.

Baumann, H., Boons, F., Bragd, A., 2002. Mapping the green product development field: engineering policy and business perspectives. J. Clean. Prod. 10, 409-425.

Ben-Gal, I., Katz, R., Bukchin, Y., 2008. Robust eco-design: a new application for air quality engineering. IIE Trans. 40, 907-918.

Bendell, T., 1989. Taguchi Methods. Elsevier Science Publishers Ltd, London.

Besseris, G.J., 2012. Eco-design in total environmental quality management: design for environment in milk-products industry. TQM J. 24, 47-58.

Bovea, M., Pérez-Belis, V., 2012. A taxonomy of ecodesign tools for integrating environmental requirements into the product design process. J. Clean. Prod. 20, $61-71$.

Box, G., Bisgaard, S., Fung, C., 1988. An explanation and critique of Taguchi's contributions to quality engineering. Qual. Reliab. Eng. Int. 4, 123-131.
Camposeco-Negrete, C., 2013. Optimization of cutting parameters for minimizing energy consumption in turning of AISI 6061 T6 using Taguchi methodology and ANOVA. J. Clean. Prod. 53, 195-203.

Carrell, J., Tate, D., Wang, S., Zhang, H.C., 2011. Shape memory polymer snap-fits for active disassembly. J. Clean. Prod. 19, 2066-2074.

Cerdan, C., Gazulla, C., Raugei, M., Martinez, E., Fullana-i-Palmer, P., 2009. Proposal for new quantitative eco-design indicators: a first case study. J. Clean. Prod. 17, 1638-1643.

Cetin, M.H., Ozcelik, B., Kuram, E., Demirbas, E., 2011. Evaluation of vegetable based cutting fluids with extreme pressure and cutting parameters in turning of AISI 304L by Taguchi method. J. Clean. Prod. 19, 2049-2056.

Choi, J., Nies, L., Ramani, K., 2008. A framework for the integration of environmental and business aspects toward sustainable product development. J. Eng. Des. 19, 431-446.

Clausing, D., 1994. Total Quality Development: A Step-By-Step Guide to World Class Concurrent Engineering. American Society of Mechanical Engineers, Cambridge Massachusetts.

Davis, T.P., 2006. Science, engineering, and statistics. Appl. Stoch. Models Bus. Industry $22,401-430$

Dean Jr. J.W., Bowen, D.E., 1994. Management theory and total quality: improving research and practice through theory development. Acad. Manag. Rev. 19, 392-418.

Fiksel, J., 2011. Design for Environment, second ed. McGraw-Hill, New York.

Ford, R.B., 1996. Process for the Conceptual Design of Robust Mechanical Systems: Going Beyond Parameter Design to Achieve World-class Quality. Stanford University, Palo Alto.

Fratila, D., Caizar, C., 2011. Application of Taguchi method to selection of optimal lubrication and cutting conditions in face milling of AlMg. J. Clean. Prod. 19, 640-645.

Gremyr, I., Hasenkamp, T., 2011. Practices of robust design methodology in practice. TQM J. 23, 47-58.

Gremyr, I., Arvidsson, M., Johansson, P., 2003. Robust design methodology: status in the Swedish manufacturing industry. Qual. Reliab. Eng. Int. 19, 285-293.

Hanafi, I., Khamlichi, A., Cabrera, F.M., Almansa, E., Jabbouri, A., 2012. Optimization of cutting conditions for sustainable machining of PEEK-CF30 using TiN tools. J. Clean. Prod. 33, 1-9.

Hasenkamp, T., Arvidsson, M., Gremyr, I., 2009. A review of practices for Robust Design methodology. J. Eng. Des. 20, 645-657.

Hatcher, G., Ijomah, W., Windmill, J., 2011. Design for remanufacture: a literature review and future research needs. J. Clean. Prod. 19, 2004-2014.

Jeyapaul, R., Shahabudeen, P., Krishnaiah, K., 2005. Quality management research by considering multi-response problems in the Taguchi method-a review. Int. J. Adv. Manuf. Technol. 26, 1331-1337.

Johansson, G., 2002. Success factors for integration of ecodesign in product development: a review of state of the art. Environ. Manag. Health 13, 98-107.

Kackar, R.N., 1985. Off-line quality control, parameter design, and the taguchi method. J. Qual. Technol. 17, 176-188.

Kackar, R.N., 1989. Taguchi's quality philosophy: analysis and commentary. In: Dehnad, K. (Ed.), Quality Control, Robust Design, and the Taguchi Method. Pacific Grove. Wadsworth \& Brooks/Cole Advanced Books \& Software, California.

Kaebernick, H., Kara, S., Sun, M., 2003. Sustainable product development and manufacturing by considering environmental requirements. Robot. Comp. Integ. Manuf. 19, 461-468.

Knight, P., Jenkins, J.O., 2009. Adopting and applying eco-design techniques: a practitioners perspective. J. Clean. Prod 17, 549-558.

Lopes Silva, D.A., Delai, I., Soares de Castro, M.A., Ometto, A.R., 2013. Quality tools applied to cleaner production programs: a first approach toward a new methodology. J. Clean. Prod. 47, 174-187.

Luttropp, C., Lagerstedt, J., 2006. EcoDesign and the ten golden rules: generic advice for merging environmental aspects into product development. J. Clean. Prod. 14, 1396-1408.

MacInnis, D.J., 2011. A framework for conceptual contributions in marketing. J. Mark. 75, 136-154.

Masui, K., Sakao, T., Kobayashi, M., Inaba, A., 2003. Applying quality function deployment to environmentally conscious design. Int. J. Qual. Reliab. Manag. 20, 90-106.

Maxwell, D., Van der Vorst, R., 2003. Developing sustainable products and services. J. Clean. Prod. 11, 883-895.

Meredith, J., 1993. Theory building through conceptual methods. Int. J. Operat. Prod. Manag. 13, 3-11.

Murphy, T.E., Tsui, K.-L., Allen, J.K., 2005. A review of robust design methods for multiple responses. Res. Eng. Des. 15, 201-215.

Phadke, M.S., 1989. Quality Engineering Using Robust Design. PTR Prentice-Hall Inc, New Jersey, USA.

Rönnbäck, ^., Witell, L., 2008. A review of empirical investigations comparing quality initiatives in manufacturing and service organizations. Manag. Serv. Qual. 18, 577-593.

Sakao, T., 2007. A QFD-centred design methodology for environmentally conscious product design. Int. J. Prod. Res. 45, 4143-4162.

Sakao, T., 2009. Quality engineering for early stage of environmentally conscious design. TQM J. 21, 182-193.

Shewhart, W.A., 1931. Economic Control of Quality of Manufactured Product. American Society for Quality.

Taguchi, G., 1986. Introduction to Quality Engineering: Designing Quality into Products and Processes. Asian Productivity Organization, Tokyo. 
Taguchi, G., 1993. Taguchi on Robust Technology Development: Bringing Quality Engineering Upstream. ASME Press, New York.

Taguchi, G., Clausing, D., 1990. Robust quality. Harv. Bus. Rev. 68, 65-75.

Taguchi, G., Phadke, M.S., 1989. Quality engineering through design optimization. In: Dehnad, K. (Ed.), Quality Control, Robust Design, and the Taguchi Method. Wadsworth \& Brooks/Cole Advanced Books \& Software, Pacific Grove, California.

Taguchi, G., Wu, Y., 1979. Introduction to Off-line Quality Control. Central Japan Quality Control Assoc.

Tarí, J.J., Molina-Azorín, J.F., 2010. Integration of quality management and environmental management systems: similarities and the role of the EFQM model. TQM J. 22, 687-701.
Thornton, A.C., Donnelly, S., Ertan, B., 2000. More than just robust design: why product development organizations still contend with variation and its impact on quality. Res. Eng. Des. 12, 127-143.

Vinodh, S., Rathod, G., 2010. Integration of ECQFD and LCA for sustainable product design. J. Clean. Prod. 18, 833-842.

Waage, S.A., 2007. Re-considering product design: a practical "road-map" for integration of sustainability issues. J. Clean. Prod. 15, 638-649.

Wiengarten, F., Pagell, M., 2012. The importance of quality management for the success of environmental management initiatives. Int. J. Prod. Econ. 140 407-415. 